Article

\title{
Technical Evaluation Method for Physical Property Changes due to Environmental Degradation of Grout-Injection Repair Materials for Water-Leakage Cracks
}

\author{
Bo Jiang ${ }^{1,2}$, Kyu-hwan $\mathrm{Oh}^{3}$, Soo-Yeon Kim ${ }^{4}$, Xingyang $\mathrm{He}^{5}$ and Sang-keun $\mathrm{Oh}^{6, *,+}$ \\ 1 School of Civil Architecture and Environment, HuBei University of Technology, Wuhan 432200, China; \\ jiangbo15@126.com \\ 2 Department of Architecture of Graduate School, Seoul National University of Science and Technology, \\ Seoul 01811, Korea \\ 3 Department of Railway Construction Engineering, Seoul National University of Science \& Technology, \\ Seoul 01811, Korea; kyuhwan.oh@seoultech.ac.kr \\ 4 Waterproofing Technology Research Center, Seoul National University of Science \& Technology, Seoul 01811, \\ Korea; ksr1115@empal.com \\ 5 School of Civil Engineering and Environment of HuBei University of Technology, Wuhan 432200, China; \\ hxycn@126.com \\ 6 School of Architecture, Seoul National University of Science and Technology, Seoul 01811, Korea \\ * Correspondence: ohsang@seoultech.ac.kr; Tel.: +82-2-970-6559 \\ + Chutian Scholar of Province of Hubei.
}

Received: 20 March 2019; Accepted: 23 April 2019; Published: 26 April 2019

\begin{abstract}
Leakage in below-grade concrete structures are repaired using various types of grout-injection materials, but the selection of optimal material types with a consideration of the environmental degradation factors are not conducted. Different degradation factors can act on the waterproofing membranes or grout-injection materials simultaneously. Especially in the early stages of installation, the injected grout materials in the cracks for leakage repair or for reforming damaged waterproofing layers are subject to complex forms of degradation factors. In such cases, physical property changes to the materials can reduce the waterproofing performance of the grout-injection materials. In this study, a technical evaluation regime is proposed for selecting the optimal repair material to be used in underground concrete structure leakage cracks. In this study, six environmental degradation factors (thermal stress, chemical corrosion, erosion due to ground water flow, hydrostatic pressure, substrate movement, and humidity on concrete surface) are identified. Corresponding evaluation methods based on the ISO TS 16774 test method series were used for each factor to assess the performance evaluation of four different types of grout-injection materials (acrylic resin, epoxy resin, polyurethane foam, and synthetic polymerized rubber gel). Based on the test results, a new comprehensive evaluation regime is presented that allows a quantitative performance comparison between each type of grout-injection material.
\end{abstract}

Keywords: grout injection material; environmental degradation factors; physical property change; water leakage crack; leakage repair; concrete structure

\section{Introduction}

\subsection{Research Background and Objectives}

The grout-injection method is used to repair leakage problems caused by concrete cracks. As waterproofing membranes are installed in the positive side of the below-grade concrete wall, the 
membrane layer is nonexposed. In such case, when the waterproofing membrane is damaged and allows the ingress of water into the interior of the concrete structures, the waterproofing layer is not directly accessible for repairs [1]. Therefore, grout injection is used to ensure the leakage crack is sealed or to fully reform the waterproofing layer in the positive side of the wall. However, numerous cases show that when the grout-injection materials are applied in below-grade concrete structures, a reopening of the leakage and defects can occur [2].

Some of the main causes are a continuous exposure to humidity, water flow, the hydrostatic pressure from underground water, the thermal stress, chemical corrosion, and the substrate movement (six types of degradation) from the surrounding environment. While cases are rare where all of these factors are simultaneously present with enough degree to affect the structure durability, these environmental degradation factors affect the structural integrity of the concrete structure simultaneously and their individual effects are difficult to predict and assess [3]. To compensate for this predicament, the materials selected for repair should be evaluated to ensure that they possess the individual resistance or response property to each of the possible degradation factors.

In underground spaces such as basements, tunnels, and below-grade structures where the existing waterproofing system or the defect source causing leakage is not exposed and accessible for facilitated repair, this is particularly problematic. If suboptimal repair materials that are easily susceptible to physical properties change are used, the waterproofing performance can be affected during the installation and early stages of their lifetime [4]. Refer to Figure 1 below for an illustrated concept of the six types of degradations in below-grade structures.

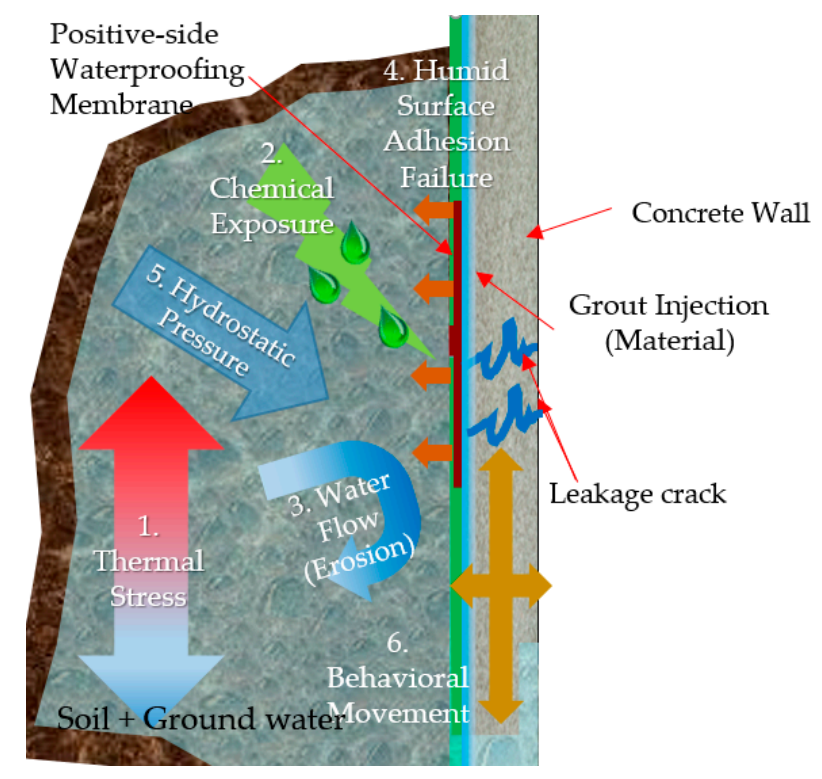

Figure 1. The six types of degradations applied to waterproofing membranes in below-grade structures.

\subsection{Degradation Mechanism Causing Physical Property Changes to Grout-Injection Materials}

Using only data based on the physical property changes of grout-injection materials, it is difficult to assess whether the grout-injection materials will be able to withstand the deterioration conditions and to maintain a stable waterproofing performance [5]. To address this issue, a new comparative evaluation criterion is proposed in this study through a technical evaluation criterion that will allow a facilitated degradation factor resistance performance comparison for the selection of an optimal type of grout-injection repair material in compliance to ISO TR 16475:2011 Guidelines for the Repair of Water-Leakage Cracks in Concrete Structures [6]. This standard identifies the required performance criteria of grout-injection materials' responses to the six types of degradation in below-grade concrete structures. Refer to Figure 2 below for the details of the six degradation factors. 


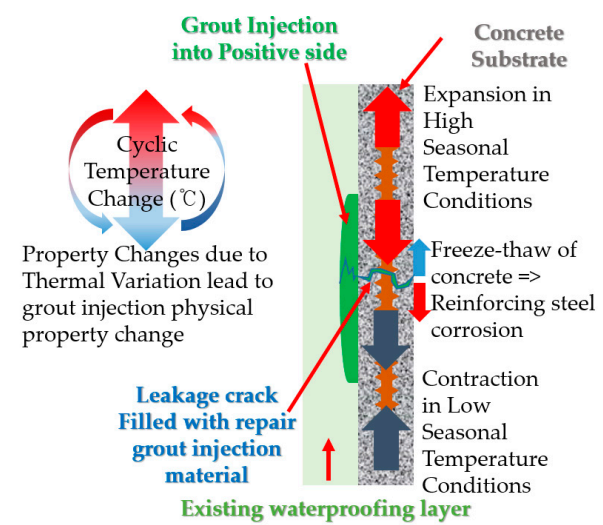

(a)

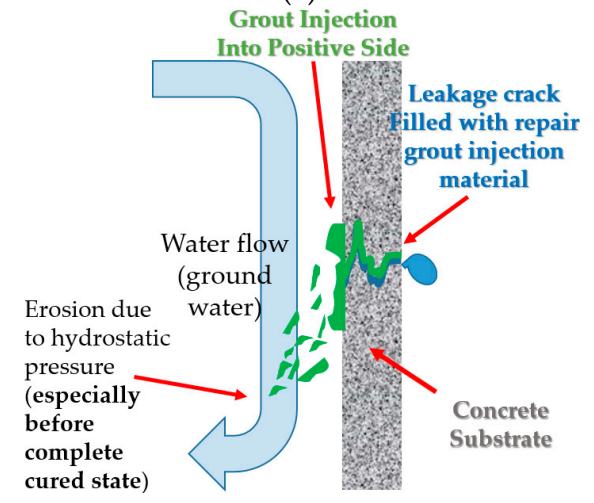

(c)

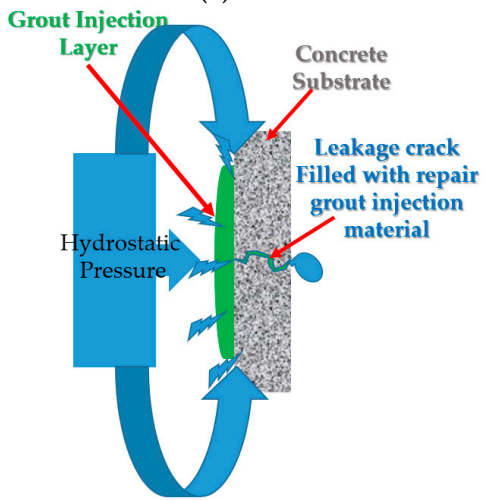

(e)

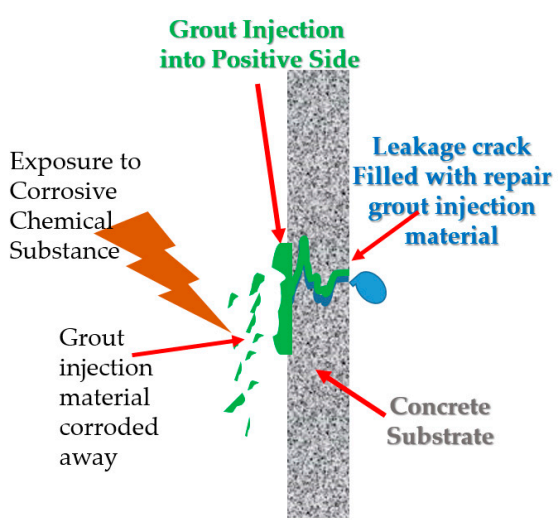

(b)

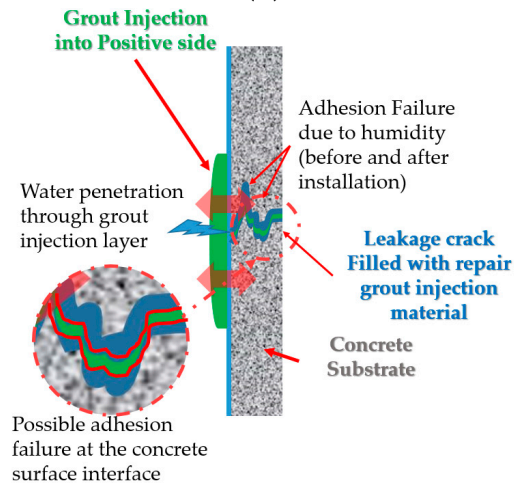

(d)

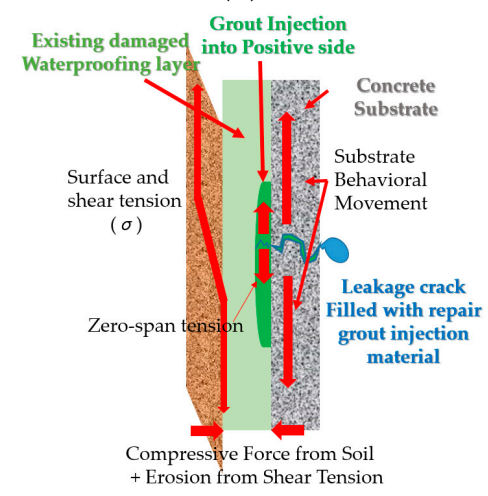

(f)

Figure 2. The six types of expected degradation conditions in the below-grade environment; (a) the cyclic thermal stress on concrete and waterproofing membrane, (b) a chemical attack on the waterproofing, (c) erosion due to hydrostatic pressure or water flow, (d) a membrane wet surface due to humidity, (e) hydrostatic pressure damage to the waterproofing membrane, and (f) the zero-span tension and shear stress applied on a waterproofing membrane.

Currently there are six separate test methods (thermal resistance, chemical resistance, washout resistance, wet surface adhesion strength, hydrostatic pressure resistance, and substrate behavior resistance) outlined in the ISO TS 16774 Test Methods for Repair Materials for Water-Leakage Cracks in Underground Concrete Structures [7]. In reference to these existing test methods, a technical evaluation regime that independently measures the physical property changes of four types of grout-injection materials due to six environmental degradation factors is proposed. This evaluation regime addresses the aforementioned concerns and proposes a new comparison regime based on the test results of three different products for each of four types of grout-injection materials (acrylic resin, epoxy resin, polyurethane foam, and synthetic polymerized rubber gel). 


\section{Grout-Injection Materials and Test Specimen Products}

\subsection{Installation Methods and Exposure Conditions of Grout-Injection Materials}

Conventionally used grout-injection materials for concrete crack repairs include acrylic resin, epoxy resin, polyurethane foam, and synthetic polymer rubberized gel (SPRG). In this paper, these four types of grout-injection repair materials were tested for their performance in compliance to the ISO TS 16774 Test Methods for Repair Materials for Water-Leakage Cracks in Underground Concrete Structures. Injection methods can be broadly categorized into two types: (1) a direct injection for leakage crack sealing (installation into the crack) and (2) a backfill injection for the repair/reformation of a damaged existing waterproofing layer (drilling at the adjacent side of the crack and injection) [8]. In the case of a direct injection method, a low-pressure injection is required to ensure localized cracking near the crack is prevented. Refer to Figure 3 below for an illustrated concept of a grout-injection repair of waterproofing membranes.

1. Direct Injection

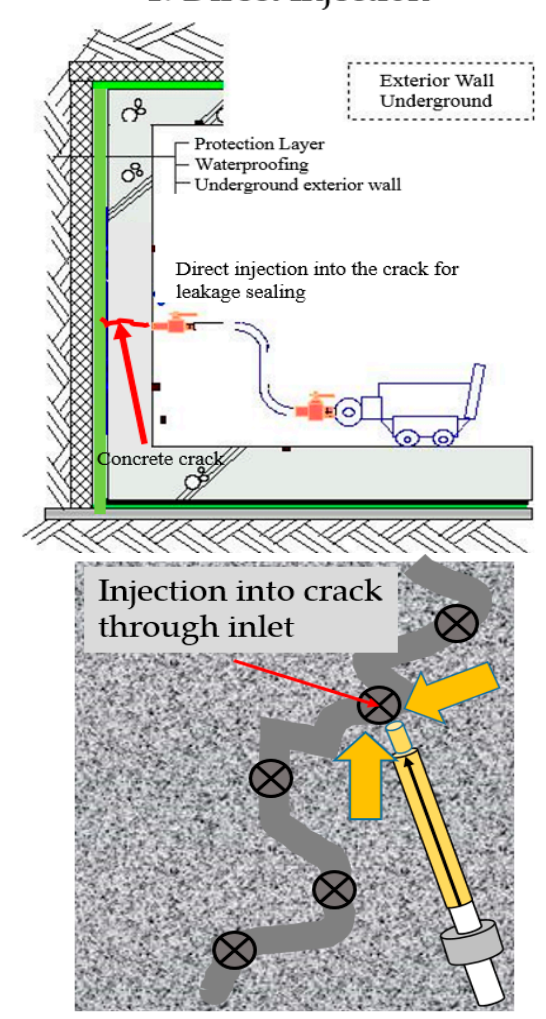

(a)
2. Backfill Injection
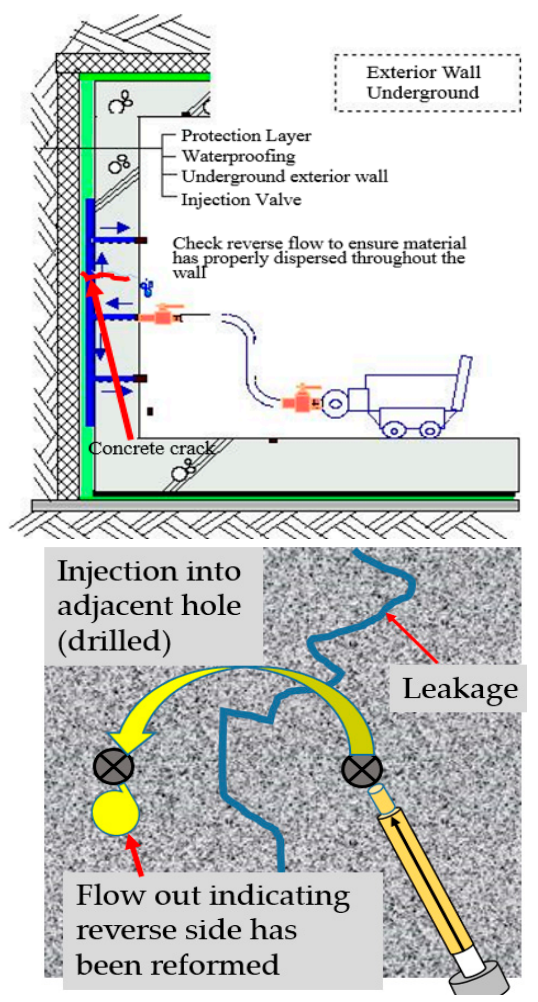

(b)

Figure 3. Grout injection in a below-grade concrete structure for the repair of a waterproofing layer: (a) the direct injection method and (b) the backfill injection method.

The level of exposure to the different types of the six degradation factors with the types of grout-injection materials can differ based on the methods (or locations) of installation and the material property at the initial stages of installation (prior to curing). Most cases of a direct injection are subject to a high influence from a continuous hydrostatic pressure even after complete installation but are not commonly affected by thermal stress (as is shown in Table 1). Due to the difference in the below-grade structure environment and the material types in Korea, the expected exposure level of degradation factors in leakage cracks only takes into account the study results obtained for the analytic hierarchy process (AHP) statistics data in Korea [9]. Refer to Table 1 for details. 
Table 1. The expected degree of exposure to degradation factors in accordance to grout-injection material repair methods in leakage cracks (analytic hierarchy process (AHP) statistics data in Korea).

\begin{tabular}{|c|c|c|c|c|c|c|c|}
\hline \multirow{2}{*}{ Material Type } & \multirow{2}{*}{$\begin{array}{l}\text { Repair } \\
\text { Method }\end{array}$} & \multicolumn{6}{|c|}{ Expected Exposure Level of Degradation Factors } \\
\hline & & $\begin{array}{l}\text { Thermal } \\
\text { Stress }\end{array}$ & $\begin{array}{l}\text { Chemical } \\
\text { Exposure }\end{array}$ & $\begin{array}{c}\text { Water } \\
\text { Flow } \\
\text { Erosion }\end{array}$ & $\begin{array}{c}\text { Wet Surface } \\
\text { Adhesion } \\
\text { Strength }\end{array}$ & $\begin{array}{l}\text { Hydrostatic } \\
\text { Pressure }\end{array}$ & $\begin{array}{c}\text { Substrate } \\
\text { Behavioral } \\
\text { Stress }\end{array}$ \\
\hline $\begin{array}{l}\text { Acrylic Resin } \\
\text { Grout }\end{array}$ & $\begin{array}{c}\text { Direct } \\
\text { injection }\end{array}$ & o & D & - & $\bullet$ & $\bullet$ & $\bullet$ \\
\hline $\begin{array}{l}\text { Epoxy Resin } \\
\text { Grout }\end{array}$ & $\begin{array}{c}\text { Direct } \\
\text { injection }\end{array}$ & 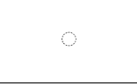 & D & - & $\bullet$ & $\bullet$ & $\bullet$ \\
\hline $\begin{array}{l}\text { Polyurethane } \\
\text { Foam }\end{array}$ & $\begin{array}{c}\text { Direct } \\
\text { injection }\end{array}$ & o & D & - & $\bullet$ & $\bullet$ & $\bullet$ \\
\hline $\begin{array}{l}\text { Synthetic Polymer } \\
\text { Rubberized Gel } \\
\text { (SPRG) Grout }\end{array}$ & $\begin{array}{l}\text { Back Fill } \\
\text { Grouting }\end{array}$ & D & 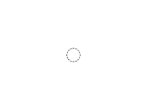 & o & $\bullet$ & D & $\bullet$ \\
\hline
\end{tabular}

Based on the above three types of expected exposure levels ( $\bullet$ : High, $\mathbf{0}$ : Moderate, and $:$ Low) outlined in Table 1, the following grout-injection repair materials were selected as specimens for assessing the physical properties change (waterproofing performance). The grout-injection material properties and specifications are introduced in the following Section 2.2.

\subsection{Properties of Test Specimen Products}

\subsubsection{Acrylic Resin Grout (Water-Based Acrylic Gel Grout)}

Most acrylic resin grouts used as leakage crack repair materials in below-grade concrete structures are commonly composed of acrylic acid polymer hydrophilic with a low viscosity and have high-hydrostatic-pressure resistance properties. The types of acrylics grout materials include acrylics, acrylates, and acrylate ester. Based on different application requirements and mixture ratios, the curing time can vary. Acrylic resin grout seals leakage cracks through their hydrophilic swelling behavior after contact and a reaction with water, but the pressure is not sufficient enough to cause localized cracking in the concrete after curing. The materials are normally injected or applied on the leakage crack immediately after mixing in order to prevent premature hydration and/or curing outside of the crack [10]. The specifications of the three types of acrylic-resin injection-grout materials tested in this study are outlined in Table 2 below.

Table 2. The acrylic-resin injection-grout material properties.

\begin{tabular}{|c|c|c|}
\hline Product Number & Components & Properties \\
\hline 1 & $\begin{array}{l}\text { Metal hydroxide aqueous solution + acrylic } \\
\text { acid + methacrylic acid), persulfate, amine } \\
\text { (redox polymerization catalyst, acrylic acid } \\
\text { salts, cross-linking agent. }\end{array}$ & $\begin{array}{l}\text { (1) Mixed viscosity: Less than } 5 \mathrm{cps} \\
\text { (2) Acrylate-based water-stop agent } \\
\text { (3) Volume expansion: } 400 \% \\
\text { (4) Curing time: } 120 \mathrm{~s}\end{array}$ \\
\hline 2 & $\begin{array}{l}\text { Acrylic acid metal salt, acrylamide, } \\
\text { triethanolamine, glycerin, potassium } \\
\text { femicyanide, sodium persulfate }\end{array}$ & $\begin{array}{l}\text { (1) Mixed viscosity: Less than } 3 \mathrm{cps} \\
\text { (2) Acrylate-based water-stop agent } \\
\text { (3) Volume swelling: } 200 \% \\
\text { (4) Elongation: } 70 \% \text { after condensation } \\
\text { AG-3 }\end{array}$ \\
\hline 3 & $\begin{array}{l}\text { Sodium polyacrylate, acrylamide- sodium } \\
\text { acrylate, } \\
\text { Water, hardener (sulfate compounds, water), } \\
\text { accelerant (triethanolamine, water) }\end{array}$ & $\begin{array}{l}\text { (1) Mixed viscosity: less than } 20 \mathrm{cps} \\
\text { (2) Acrylic seal grouting agent } \\
\text { (3) Solubility: Soluble in water } \\
\text { (4) Boiling point/melting point: } 100^{\circ} \mathrm{C} /-10^{\circ} \mathrm{C}\end{array}$ \\
\hline
\end{tabular}




\subsubsection{Hydrophilic Epoxy Resin Grout}

Epoxy resins have relatively high tensile and compressive strengths. The low viscosity of pre-cured epoxy resin injection grouts allows an easier installation into concrete cracks. Epoxy resin grouts require thorough mixing with the main agent and a curing compound (hardener), such as an amine or a polyamide. This material is commonly mixed while being injected through separate high-pressure hoses that are connected to a single nozzle head. This is to prevent premature curing; thus, the installation time should be set relatively shorter [11].

Hydrophilic epoxy resins have a low tensile strength but, in general, have a higher adhesion performance on concrete substrate surfaces [12]. The specifications of the three types of epoxy-resin injection-grout materials tested in this study are outlined in Table 3 below.

Table 3. The epoxy-resin injection-grout material properties.

\begin{tabular}{|c|c|c|}
\hline Product Number & Components/Ratio & Properties \\
\hline 1 & $\begin{array}{c}\text { Epoxy resin }+ \text { amine } \\
\text { Main Agent: Hardener }=2: 1\end{array}$ & $\begin{array}{l}\text { (1) Non-shrinking low-viscosity epoxy resin } \\
\text { (2) Pot life: } 90 \pm 5 \min \left(20 \pm 1^{\circ} \mathrm{C}\right) \\
\text { (3) Cure time: About } 8 \mathrm{~h}\left(30 \pm 5^{\circ} \mathrm{C}\right)\end{array}$ \\
\hline 2 & $\begin{array}{l}\text { Epoxy resin + polyamide amine; } \\
\text { Main Agent: Hardener = 2:1 }\end{array}$ & $\begin{array}{l}\text { (1) Two-component low-viscosity wet-type grout } \\
\text { (2) Pot life: } 60 \pm 2 \min \left(25 \pm 1^{\circ} \mathrm{C}\right) \\
\text { (3) Cure time: } 24-36 \mathrm{~h}\left(25 \pm 1^{\circ} \mathrm{C}\right)\end{array}$ \\
\hline 3 & $\begin{array}{c}\text { Elastic epoxy sealant } \\
\text { Main Agent: Hardener }=1: 1\end{array}$ & $\begin{array}{l}\text { (1) Two-component epoxy elastic sealing grout } \\
\text { (2) Pot life: } 60 \pm 2 \min \left(21 \pm 1^{\circ} \mathrm{C}\right) \\
\text { (3) Cure time: } 24-36 \mathrm{~h}\left(21 \pm 1^{\circ} \mathrm{C}\right)\end{array}$ \\
\hline
\end{tabular}

\subsubsection{Polyurethane Foam Resin Grout}

Polyurethane foam resin injection grout reacts with water to provide protection against leakage cracks in concrete structures. Their short reaction time with water transforms the resin into a foam structure inside the crack. Polyurethane foam grouts consist of a polyurethane resin that reacts with water to form a closed-cell foam layer or gel (hydrophilic types) inside the water leakage crack when injected. Polyurethane grouts are mainly used as a temporary measure to stop water-leakage, and a secondary injection installation of a reinforcing repair material is commonly applied afterwards [13]. The specifications of the three types of polyurethane foam injection grout materials tested in this study are outlined in Table 4 below.

Table 4. The polyurethane-foam injection-grout material properties.

\begin{tabular}{|c|c|c|}
\hline Product Number & Components & Properties \\
\hline 1 & $\begin{array}{c}\text { Reaction type polyurethane } \\
\text { polymers } \\
\text { Xylene: } 4 \%\end{array}$ & $\begin{array}{l}\text { (1) Single-component rapid-curing elastic } \\
\text { polyurethane } \\
\text { (2) Solubility: Insoluble } \\
\text { (3) Specific gravity }\left(20^{\circ} \mathrm{C}\right): 1.26 \\
\text { (4) Flashpoint: } 65^{\circ} \mathrm{C}\end{array}$ \\
\hline 2 & $\begin{array}{l}\text { Hydrophobic rigid Polyurethane } \\
\text { foam }\end{array}$ & $\begin{array}{l}\text { (1) Double-component high-strength } \\
\text { polyurethane } \\
\text { (2) Viscosity: } 532 \text { (resin) } \mathrm{cps} / 23.1^{\circ} \mathrm{C} \\
\text { (3) Initial/complete cure pot life: } 60 \mathrm{~min} / 24 \mathrm{~h} \text { at } \\
\text { room temperature }\end{array}$ \\
\hline 3 & $\begin{array}{l}\text { Polyurethane resin, Acetone } \\
(\mathrm{CH} 3 \mathrm{CoCH} 3) \text { and other additives }\end{array}$ & $\begin{array}{l}\text { (1) Single-component polyurethane foam } \\
\text { (2) Solubility: } 1.3 \mathrm{~g} / 100 \mathrm{~mL} \\
\text { (3) Specific gravity }\left(20^{\circ} \mathrm{C}\right): 1.37 \\
\text { (4) Viscosity: } 200-500 \mathrm{cps} / 25^{\circ} \mathrm{C}\end{array}$ \\
\hline
\end{tabular}




\subsubsection{Synthetic Rubber Polymer Gel Grout}

Synthetic rubber polymer gel (SPRG) grout is a mixture of a specialized macromolecular resin, including rubberized polymer gel, and asphalt compounds. These types of materials have a strong adhesive bond to wet substrate surface. This repair material also has a high response property to the concrete joint or crack movement due to the naturally high elastic property of the rubberized gel component $[14,15]$. SPRG displays a high performance in both low and high temperatures and humidity conditions. The specifications of the three types of SPRG injection-grout materials tested in this study are outlined in Table 5 below.

Table 5. The Synthetic rubber polymer gel (SRGP) injection grout material properties.

\begin{tabular}{|c|c|c|}
\hline Product Number & Components/Ratio & Properties \\
\hline 1 & $\begin{array}{l}\text { Acrylamide, persulfate (mixed with } \\
\text { one or two kinds of sodium, } \\
\text { ammonium, and potassium), asphalt }\end{array}$ & $\begin{array}{l}\text { (1) Solids: } 85-90 \% \\
\text { (2) High-viscosity + low-viscosity non-curable } \\
\text { composite aqueous gel }\end{array}$ \\
\hline 2 & $\begin{array}{l}\text { Asphalt, inorganic fillers, asphalt } \\
\text { modifier, strengthening agent, } \\
\text { heat resistance agent, adhesion } \\
\text { reinforcement agent, curing additives, } \\
\text { rubberized polymer etc. }\end{array}$ & $\begin{array}{l}\text { (1) Solids: } 95-99 \% \\
\text { (2) High-viscosity non-curable mastic asphalt } \\
\text { (3) Polar covalent bond structure of hydrophilic } \\
\text { and lipophilic groups }\end{array}$ \\
\hline 3 & $\begin{array}{l}\text { Asphalt, bentonite, oil, rubber, water } \\
\text { soluble, polymer resin, etc. }\end{array}$ & $\begin{array}{l}\text { (1) Solids: } 90-95 \% \\
\text { (2) Highly adhesive non-curable bentonite }\end{array}$ \\
\hline
\end{tabular}

\section{Evaluation Methods of Grout-Injection Material}

Physical property change assessments of grout-injection materials with the regimes presented in the ISO TS 16774 test methods can only be conducted in a technical matter, as laboratory results and the test designs will not be able to realistically simulate the actual site conditions. It should be noted that the degree and length of degradations that are applied in the following test regimes are exclusive to the standards in Korea and that the subsequent results serve only as a demonstration of the technical evaluation method.

Under these conditions, the physical properties of the grout-injection materials (loss of mass, adhesion strength, and impermeability) are first measured, and based on the measurement results, property change ratios are calculated within the range of 100\%. A higher change ratio of a given property indicates a higher risk of waterproofing performance deterioration, and a lower change ratio indicates a stable waterproofing performance. Based on the prescribed degree of degradation, property change ratios can exceed the $100 \%$. To account for such cases, maximum change ratios must be given to establish a comparison parameter. For this demonstration, individual test method variables were set in compliance to the environmental degradation testing conditions outlined in KS F 4935 [16]. Specimen assembly, the six test methods, and ratio calculation methods are as follows.

\subsection{Specimen Structures}

For the testing of the grout-injection material properties in relation to the subject degradation conditions, specialized specimens were designed. In the thermal stress resistance, hydrostatic pressure resistance, and substrate behavioral stress resistance testing methods, the specimen of Figure 4 was used. 


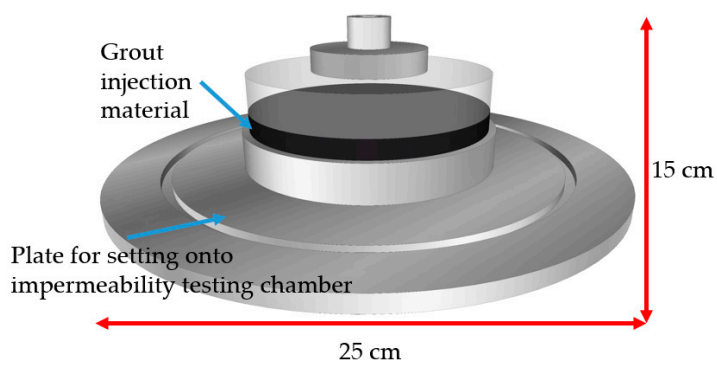

(a)

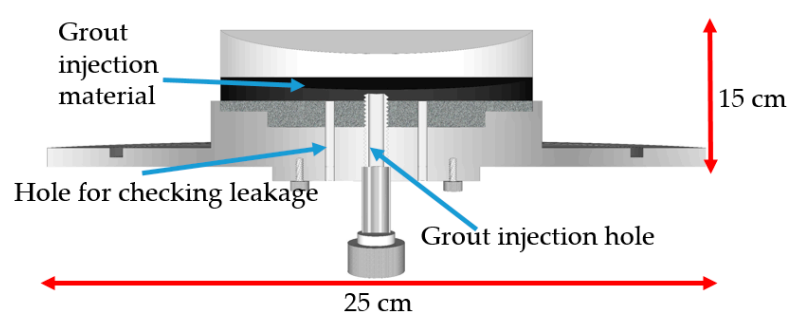

(b)

Figure 4. The specimen for thermal stress resistance, hydrostatic pressure resistance, and substrate behavioral stress resistance testing: (a) specimen concept and (b) specimen inner structure.

In the chemical exposure resistance and water flow erosion resistance testing, grout-injection material is placed in a petri dish, which is subsequently covered with a nonwoven fabric layer. This specimen is inside a container filled with a mixed chemical solution and a water flow simulation chamber respectively. Refer to the below Figure 5 for details.

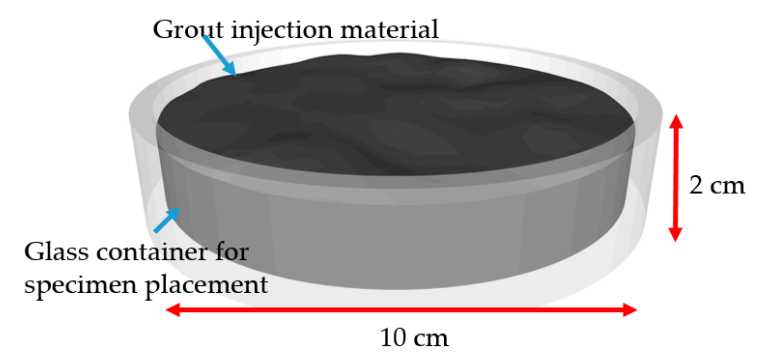

Figure 5. The specimen for chemical exposure resistance and water flow erosion resistance testing.

In the test method for wet surface adhesion strength testing, a specimen structure comprised of two acrylic substrate parts is used, where the grout injection material is injected in between the two parts. Refer to Figure 6 for details.

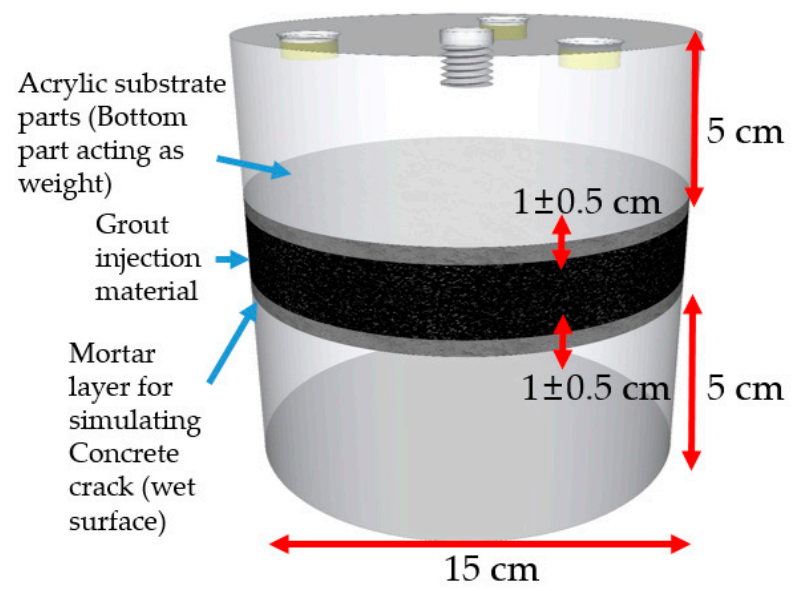

Figure 6. The specimen for wet surface adhesion strength testing.

\subsection{Grout-Injection Materials Property Change Evaluation Regime}

\subsubsection{Evaluation for Property Changes Due to Thermal Stress}

The specimens from Figure 4 in Section 3.1 are placed under thermal stress cycling in a temperature chamber. With one cycle consisting of a 1-h placement in $20^{\circ} \mathrm{C}$ temperature, $2 \mathrm{~h}$ in $60^{\circ} \mathrm{C}$, and $1 \mathrm{~h}$ in $-20^{\circ} \mathrm{C}$ condition, each specimen is placed under 20 cycles of thermal stressing. Afterwards, changes 
to the waterproofing performance to the specimens is inspected through a permeability testing of Figure 7 for $60 \mathrm{~min}$, and the minute interval at which leakage occurs is recorded. Refer to the below Figure 7 for an illustration test method.
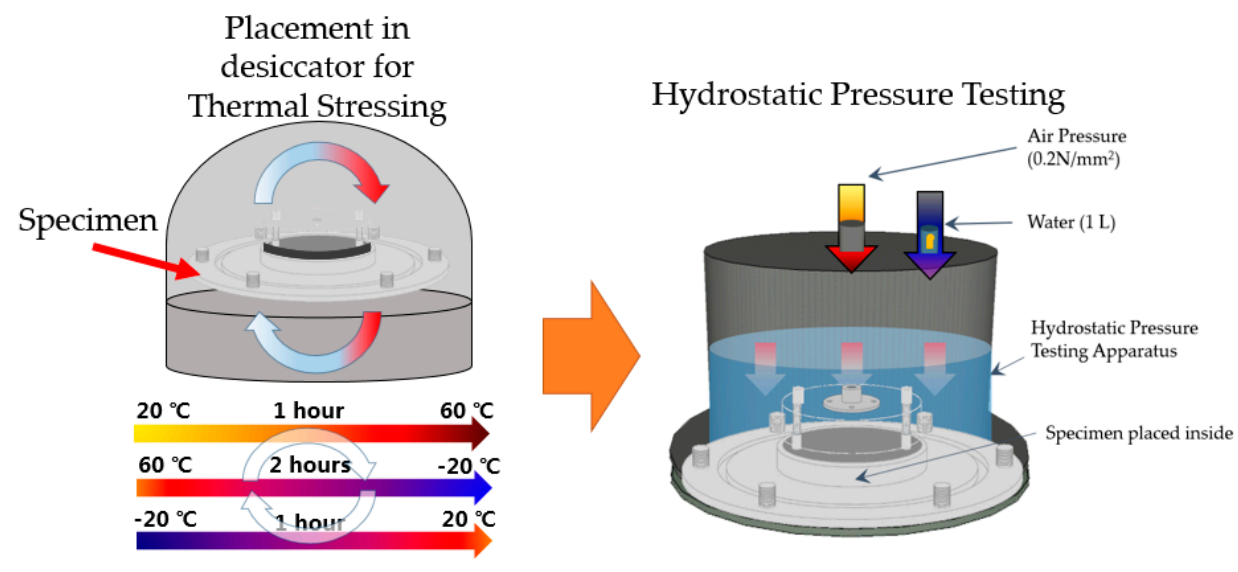

Figure 7. The test method outline and apparatus.

The waterproofing property changes with respect to impermeability due to thermal cycling due to thermal stress is calculated into a ratio to provide a waterproofing property change index for a relative comparison. The impermeability failure ratio of the grout-injection repair material is measured with the following equation based on the results of the hydrostatic pressure resistance testing after thermal stressing.

$$
\left(\mathrm{T}-t_{i}\right) / \mathrm{T} \times 100 \%=\mathrm{T}_{t s}
$$

where $\mathrm{T}$ is the Test duration (60 min as in accordance to KS F 4935); $t_{i}$ is the average number of minutes taken before leakage occurred during hydrostatic pressure testing ( $\mathrm{min}$ ); and $T_{t s}$ is the impermeability degradation ratio $(\%)$.

\subsubsection{Evaluation Method for Property Change Due to Chemical Exposure}

The specimens from Figure 5 in Section 3.1 are used for this testing. The mass of the specimens before testing are measured and then placed in containers filled with mixed chemical solutions $(0.1 \%$ $\mathrm{HCl}, 0.2 \% \mathrm{H}_{2} \mathrm{SO}_{4}, 0.2 \% \mathrm{HNO}_{3}, 3 \% \mathrm{NaOH}$, and $3 \% \mathrm{NaCl}$ ). After $72 \mathrm{~h}$ of exposure in each of the containers, the specimens are removed from the container and dried in desiccators until they reach a constant mass. The mass of the specimens is calculated up to two decimal places in grams (or the percentage of the remaining material in the container). Refer to the below Figure 8 for an illustration of test method.

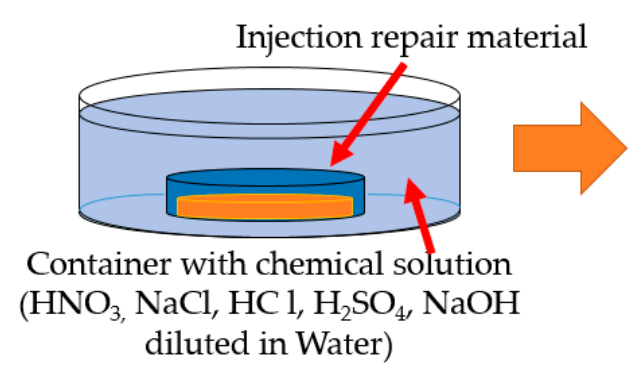

(a)

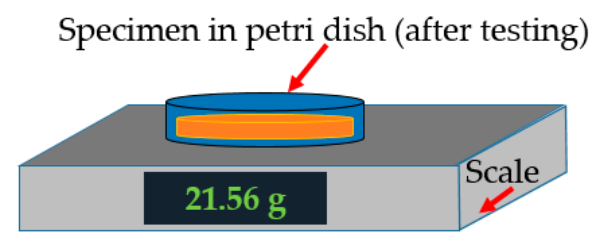

Mass measurement after exposure to chemical substance solution

(b)

Figure 8. The test method apparatus: (a) exposure to the chemical solution and (b) the mass measurement after exposure. 
The waterproofing property change with respect to a mass loss due to corrosion or a chemical reaction with the mixed solutions is calculated into a ratio to provide a measurement index for a relative comparison. The mass loss ratio of the grout-injection material is measured with the following equation based on the results of the chemical exposure resistance test results.

$$
\left\{w /\left(m \times m_{l t}\right)\right\} \times 100 \%(!)=\mathrm{C}_{l}
$$

where $m$ is the mass of the grout-injection material before testing $(\mathrm{g}) ; m_{l t}$ is the mass loss threshold percentage (the mass lost should not be more than $15 \%$ as in accordance to KS F 4935 standard); $w$ is the average lost mass of the injection material during the chemical solution exposure $(\mathrm{g})$; and $C_{l}$ is the mass loss ratio relative to the standard mass loss threshold (\%).

\subsubsection{Evaluation Method for Property Changes Due to Water Flow Erosion}

Specimens from Figure 5 in Section 3.1 are placed in a water flow simulation chamber. The mass of the specimens is measured prior to the immersion in the water flow chamber (up to two decimal places in grams). The specimens are exposed to $0.2 \mathrm{~m} / \mathrm{s}$ of water flow for $48 \mathrm{~h}$. After the test cycles, the specimens are removed from the water flow apparatus and are placed in a desiccator until the specimen reaches a constant mass. Afterwards, the mass of the specimens is measured down to two decimal places and recorded (or the percentage of the remaining material in the container). Refer to the below Figure 9 for an illustration of the test method.

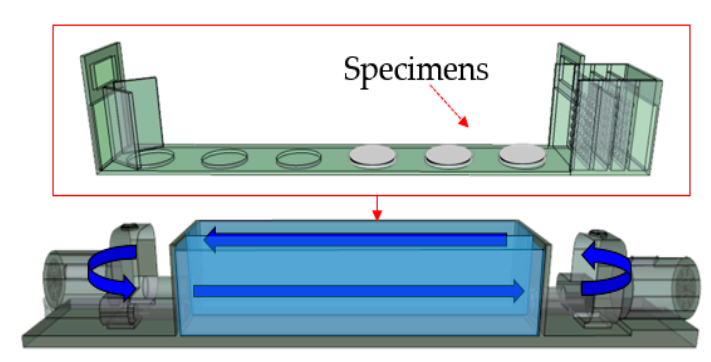

Specimens placed inside apparatus

(a)

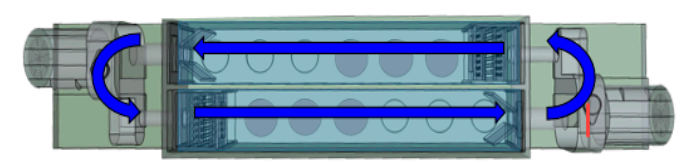

Specimens subject to constant water flow $(0.2 \mathrm{~m} / \mathrm{s})$

(b)

Figure 9. The test method apparatus: (a) the specimen placement and (b) the water flow testing.

The waterproofing property change with respect to the mass loss due to erosion from exposure to the water flow or hydrostatic pressure is calculated into a ratio to provide a measurement index for a relative comparison. The mass loss ratio of the grout-injection material is measured with the following equation based on the results of the washout resistance test results.

$$
\left\{w /\left(m \times m_{l t}\right)\right\} \times 100 \%(!)=W_{l}
$$

where $m$ is the mass of the grout-injection material before testing $(\mathrm{g}) ; m_{l t}$ is the mass loss threshold percentage (the mass lost should not be more than $15 \%$ as in accordance to KS F 4935 standard); $w$ is the lost mass of the grout-injection material after the water flow cycle (g); and $W_{l}$ is the mass loss ratio relative to standard mass loss threshold (\%)

\subsubsection{Evaluation Method for Wet Surface Adhesion Strength}

Specimens from Figure 6 in Section 3.1 are installed on the wet surface adhesion testing apparatus to measure the adhesion maintenance duration of the grout-injection repair materials. The specimen adhesion on a wet concrete surface is tested by letting the weight of the bottom concrete substrate part exert its weight on the repair material adhesion at the interface on the wet concrete surface. The duration for which the material can maintain adhesion or cohesive strength is measured up to 
a maximum of $60 \mathrm{~s}$. The point at which an adhesion or cohesion failure of the material occurs is measured and recorded. Refer to Figure 10 for an illustration of the test method.

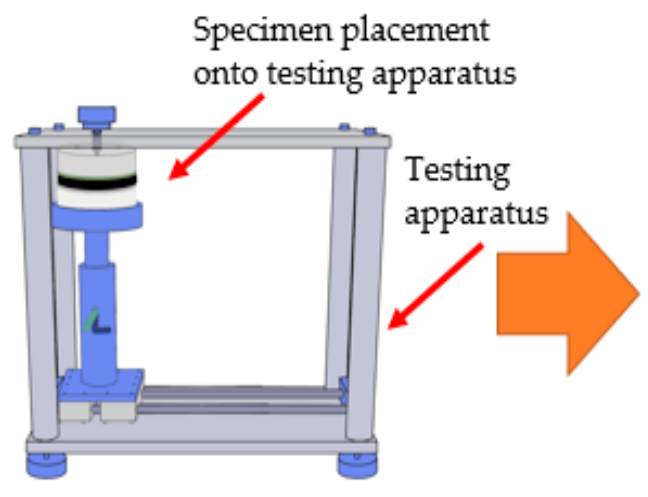

(a)

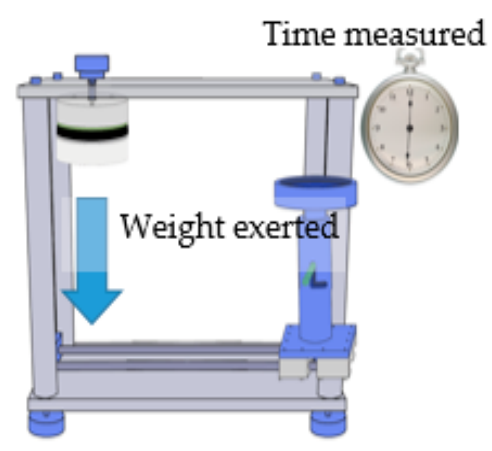

(b)

Figure 10. The test method apparatus: (a) the specimen installation onto the wet surface adhesion strength testing apparatus and $(\mathbf{b})$ removing the bottom platform and initiating testing.

The waterproofing property change with respect to adhesion performance due to a humid surface installation of the grout-injection material is calculated into a ratio to provide a measurement index for a relative comparison. The adhesion or cohesion failure ratio of the grout-injection material is measured with the following equation.

$$
\left(\mathrm{T}-t_{i}\right) / \times 100 \%=\mathrm{A}_{i f}
$$

where $\mathrm{T}$ is the Test duration (60 $\mathrm{s}$ as in accordance to KS F 4935); $t_{i}$ is the average number of minutes taken before an adhesion/the cohesion failure occurred during hydrostatic pressure testing (s); and $\mathrm{A}_{i f}$ is the adhesion degradation ratio indicating how quickly the material fails (\%).

\subsubsection{Evaluation Method Property Changes Due to Hydrostatic Pressure}

The specimen from Figure 4 in Section 3.1 is placed in a permeability testing chamber filled with $1 \mathrm{~L}$ of water. An air pressure of $0.2 \mathrm{~N} / \mathrm{mm}^{2}$ is applied through a pressure inlet located at the top of the chamber, and the specimen is subjected to hydrostatic pressure for $60 \mathrm{~min}$. The minute interval at which leakage occurs is measured. Refer to the below Figure 11 for illustration of the test method.

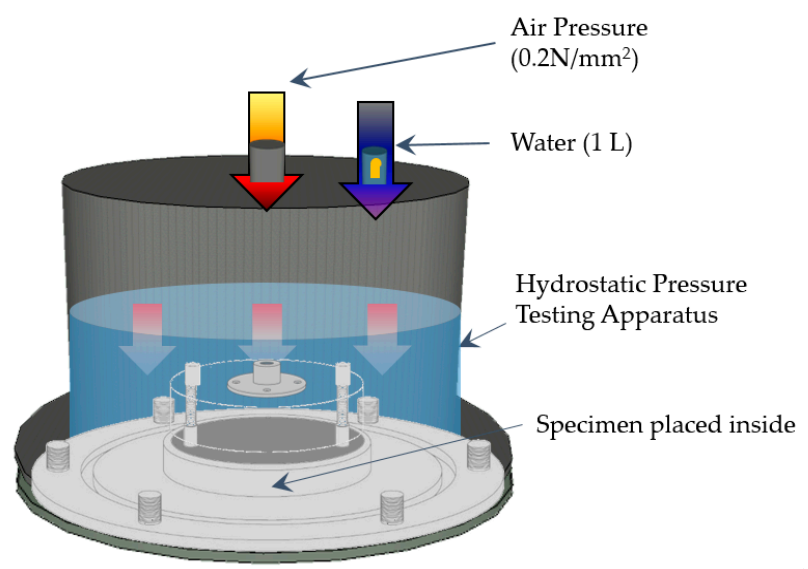

Figure 11. The test method apparatus: hydrostatic pressure testing.

The waterproofing property changes with respect to impermeability due to hydrostatic pressure is calculated into a ratio to provide a waterproofing property change index for a relative comparison. 
The impermeability failure ratio of the grout-injection repair material is measured with the following equation based on the results of the hydrostatic pressure resistance testing.

$$
\left(\mathrm{T}-t_{i}\right) / \mathrm{T} \times 100 \%=\mathrm{T}_{h p}
$$

where $\mathrm{T}$ is the test duration (60 $\mathrm{min}$ as in accordance to KS F 4935); $t_{i}$ is the average number of minutes taken before a leakage occurred during hydrostatic pressure testing $(\mathrm{min})$; and $\mathrm{T}_{h p}$ is the impermeability degradation ratio (\%).

\subsubsection{Evaluation Method for Property Changes Due to Substrate Behavioral Stress}

The specimen from Figure 4 in Section 3.1 is subjected to a behavioral stress of 600 movement cycles of a 10-mm displacement at a rate of $50 \mathrm{~mm} / \mathrm{min}$ using a universal testing machine apparatus. Afterwards, changes to the waterproofing property to the specimens are inspected through a permeability testing (hydrostatic pressure of $0.2 \mathrm{~N} / \mathrm{mm}$ ) for $60 \mathrm{~min}$, and the minute interval at which leakage occurs is recorded. Refer to the below Figure 12 for an illustration of the test method.

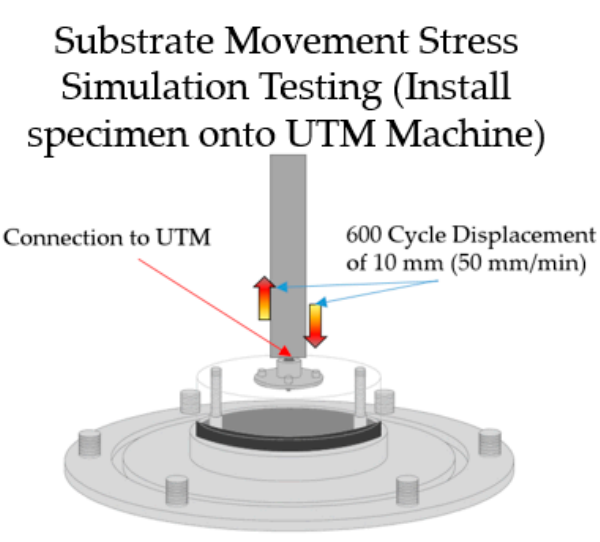

(a)

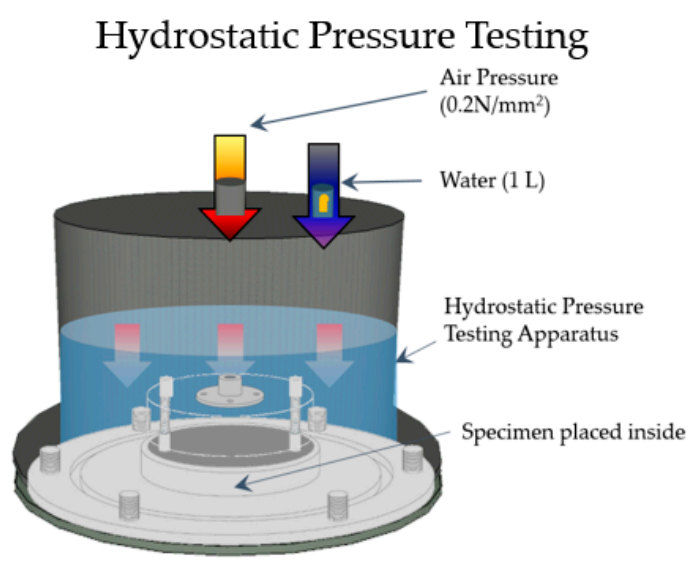

(b)

Figure 12. The substrate behavior resistance test method: (a) the substrate behavioral movement cycling procedure and (b) the permeability testing (hydrostatic pressure testing).

The waterproofing property changes with respect to impermeability after the substrate behavioral movement is calculated into a ratio to provide a waterproofing property change index for a relative comparison. The impermeability failure ratio of the SPRG is measured with the following equation based on the results of the hydrostatic pressure resistance testing after subjection to substrate behavioral movement.

$$
\left(\mathrm{T}-t_{i}\right) / \mathrm{T} \times 100 \%=\mathrm{T}_{s b}
$$

where $\mathrm{T}$ is the test duration (60 $\mathrm{min}$ as in accordance to KS F 4935); $t_{i}$ is the average number of minutes taken before leakage occurred during hydrostatic pressure testing ( $\mathrm{min}$ ); and $\mathrm{T}_{s b}$ is the impermeability degradation ratio indicating how quickly material failure occurred $(\%)$.

\section{Evaluation Results}

\subsection{Property Change to the Four Types of Grout-Injection Materials after Degradation Effects}

The following tables present the technical evaluation results of the four respective grout-injection materials assessed in compliance to the respective evaluation methods outlined in the six test methods. Refer to the below Tables 6-8 for details. 
Table 6. The evaluation results of the acrylic-resin grout-injection material.

\begin{tabular}{|c|c|c|c|c|c|c|c|}
\hline \multicolumn{2}{|c|}{ Specimens } & \multirow{2}{*}{$\begin{array}{l}\text { Thermal } \\
\text { Stress } \\
\text { (Leakage } \\
\text { Time, min) }\end{array}$} & \multirow{2}{*}{$\begin{array}{l}\text { Chemical } \\
\text { Erosion } \\
\text { (Mass } \\
\text { Loss, \%) }\end{array}$} & \multirow{2}{*}{$\begin{array}{l}\text { Water } \\
\text { Flow } \\
\text { Erosion } \\
\text { (Mass } \\
\text { Loss, \%) }\end{array}$} & \multirow{2}{*}{$\begin{array}{l}\text { Wet Surface } \\
\text { Adhesion } \\
\text { Strength } \\
\text { (De-Bonding } \\
\text { Time, s) }\end{array}$} & \multirow{2}{*}{$\begin{array}{c}\text { Hydrostatic } \\
\text { Pressure } \\
\text { (Leakage } \\
\text { Time, min) }\end{array}$} & \multirow{2}{*}{$\begin{array}{c}\text { Substrate } \\
\text { Behavioral } \\
\text { Stress } \\
\text { (Leakage } \\
\text { Time, min) }\end{array}$} \\
\hline Materials & No. & & & & & & \\
\hline \multirow{4}{*}{$\begin{array}{c}\text { Acrylic } \\
\text { A }\end{array}$} & 1 & 30 & 8.9 & 40.76 & 60 & 29 & 0 \\
\hline & 2 & 25 & 9.1 & 48.43 & 60 & 22 & 0 \\
\hline & 3 & 27 & 5.7 & 51.57 & 60 & 52 & 0 \\
\hline & Avg & 22 & 7.9 & 46.92 & 60 & 34 & 0 \\
\hline \multirow{4}{*}{$\begin{array}{c}\text { Acrylic } \\
\text { B }\end{array}$} & 1 & 34 & 6.7 & 24.19 & 54 & 60 & 0 \\
\hline & 2 & 21 & 5.2 & 20.19 & 46 & 52 & 60 \\
\hline & 3 & 42 & 7.9 & 54.02 & 39 & 60 & 60 \\
\hline & Avg & 32 & 6.6 & 32.80 & 46 & 57 & 40 \\
\hline \multirow{4}{*}{$\begin{array}{c}\text { Acrylic } \\
\text { C }\end{array}$} & 1 & 60 & 5.9 & 39.76 & 45 & 60 & 60 \\
\hline & 2 & 23 & 4.8 & 22.05 & 60 & 14 & 60 \\
\hline & 3 & 60 & 5.8 & 29.00 & 49 & 60 & 60 \\
\hline & Avg & 48 & 5.5 & 30.27 & 60 & 60 & 60 \\
\hline
\end{tabular}

Table 7. The evaluation results of the epoxy-resin grout-injection materials.

\begin{tabular}{|c|c|c|c|c|c|c|c|}
\hline \multicolumn{2}{|c|}{ Specimens } & \multirow{2}{*}{$\begin{array}{l}\text { Thermal } \\
\text { Stress } \\
\text { (Leakage } \\
\text { Time, min) }\end{array}$} & \multirow{2}{*}{$\begin{array}{l}\text { Chemical } \\
\text { Erosion } \\
\text { (Mass } \\
\text { Loss, \%) }\end{array}$} & \multirow{2}{*}{$\begin{array}{l}\text { Water } \\
\text { Flow } \\
\text { Erosion } \\
\text { (Mass } \\
\text { Loss, \%) }\end{array}$} & \multirow{2}{*}{$\begin{array}{l}\text { Wet Surface } \\
\text { Adhesion } \\
\text { Strength } \\
\text { (De-Bonding } \\
\text { Time, s) }\end{array}$} & \multirow{2}{*}{$\begin{array}{l}\text { Hydrostatic } \\
\text { Pressure } \\
\text { (Leakage } \\
\text { Time, min) }\end{array}$} & \multirow{2}{*}{$\begin{array}{c}\text { Substrate } \\
\text { Behavioral } \\
\text { Stress } \\
\text { (Leakage } \\
\text { Time, min) }\end{array}$} \\
\hline Materials & No. & & & & & & \\
\hline & 1 & 60 & 12.1 & 1 & 60 & 60 & 43 \\
\hline Epoxy & 2 & 60 & 9.8 & 9 & 60 & 60 & 60 \\
\hline \multirow[t]{3}{*}{ A } & 3 & 60 & 11.2 & 1 & 60 & 60 & 24 \\
\hline & Avg & 60 & 11.0 & 4 & 60 & 60 & 42.33 \\
\hline & 1 & 44 & 10.4 & 5 & 60 & 60 & 51 \\
\hline Epoxy & 2 & 51 & 9.5 & 3 & 60 & 60 & 27 \\
\hline \multirow[t]{2}{*}{ B } & 3 & 42 & 10.0 & 3 & 60 & 60 & 29 \\
\hline & Avg & 46 & 10.0 & 4 & 60 & 60 & 35.67 \\
\hline & 1 & 53 & 8.0 & 6 & 60 & 54 & 0 \\
\hline Epoxy & 2 & 36 & 9.0 & 7 & 60 & 23 & 0 \\
\hline \multirow[t]{2}{*}{ C } & 3 & 49 & 7.8 & 6 & 60 & 47 & 0 \\
\hline & Avg & 46 & 8.2 & 6 & 60 & 41.33 & 0 \\
\hline
\end{tabular}

Table 8. The evaluation results of the polyurethane-foam grout-injection material.

\begin{tabular}{|c|c|c|c|c|c|c|c|}
\hline \multicolumn{2}{|c|}{ Specimens } & \multirow{2}{*}{$\begin{array}{l}\text { Thermal } \\
\text { Stress } \\
\text { (Leakage } \\
\text { Time, min) }\end{array}$} & \multirow{2}{*}{$\begin{array}{l}\text { Chemical } \\
\text { Erosion } \\
\text { (Mass } \\
\text { Loss, \%) }\end{array}$} & \multirow{2}{*}{$\begin{array}{c}\text { Water } \\
\text { Flow } \\
\text { Erosion } \\
\text { (Mass } \\
\text { Loss, \%) }\end{array}$} & \multirow{2}{*}{$\begin{array}{l}\text { Wet Surface } \\
\text { Adhesion } \\
\text { Strength } \\
\text { (De-Bonding } \\
\text { Time, s) }\end{array}$} & \multirow{2}{*}{$\begin{array}{c}\text { Hydrostatic } \\
\text { Pressure } \\
\text { (Leakage } \\
\text { Time, min) }\end{array}$} & \multirow{2}{*}{$\begin{array}{c}\text { Substrate } \\
\text { Behavioral } \\
\text { Stress } \\
\text { (Leakage } \\
\text { Time, min) }\end{array}$} \\
\hline Materials & No. & & & & & & \\
\hline & 1 & 12 & 15.5 & 4 & 14 & 15 & 3 \\
\hline Urethane & 2 & 9 & 14.9 & 10 & 2 & 23 & 0 \\
\hline \multirow[t]{2}{*}{$\mathrm{A}$} & 3 & 34 & 17.0 & 15 & 6 & 14 & 1 \\
\hline & Avg & 18.33 & 15.8 & 10 & 7.33 & 17.33 & 1.33 \\
\hline & 1 & 5 & 16.9 & 8 & 0 & 10 & 4 \\
\hline Urethane & 2 & 7 & 17.2 & 8 & 1 & 9 & 0 \\
\hline \multirow[t]{2}{*}{ B } & 3 & 8 & 15.8 & 4 & 6 & 6 & 3 \\
\hline & Avg & 6.67 & 16.6 & 7 & 2.33 & 8.33 & 2.33 \\
\hline & 1 & 6 & 15.2 & 20 & 2 & 5 & 0 \\
\hline Urethane & 2 & 14 & 16.3 & 21 & 31 & 26 & 2 \\
\hline \multirow[t]{2}{*}{ C } & 3 & 3 & 17.0 & 23 & 13 & 43 & 14 \\
\hline & Avg & 7.67 & 16.2 & 21 & 15.33 & 24.67 & 5.33 \\
\hline
\end{tabular}




\subsubsection{Acrylic-Resin Grout-Injection Material}

The evaluation results on property change of the acrylic-resin grout-injection material are displayed below in Table 6.

\subsubsection{Epoxy-Resin Grout-Injection Material}

The evaluation results on property change of the epoxy-resin grout-injection material measurement results are displayed below in Table 7.

\subsubsection{Polyurethane-Foam Grout-Injection Material}

The evaluation results on property change of the polyurethane-foam grout-injection material measurement results are displayed below in Table 8.

\subsubsection{SPRG Grout-Injection Material}

The evaluation results on property changes of the SPRG grout-injection material measurement results are displayed below in Table 9.

Table 9. The evaluation results of SPRG grout-injection materials.

\begin{tabular}{|c|c|c|c|c|c|c|c|}
\hline \multicolumn{2}{|c|}{ Specimens } & \multirow{2}{*}{$\begin{array}{l}\text { Thermal } \\
\text { Stress } \\
\text { (Leakage } \\
\text { Time, min) }\end{array}$} & \multirow{2}{*}{$\begin{array}{c}\text { Chemical } \\
\text { Erosion } \\
\text { (Mass } \\
\text { Loss, \%) }\end{array}$} & \multirow{2}{*}{$\begin{array}{c}\text { Water } \\
\text { Flow } \\
\text { Erosion } \\
\text { (Mass } \\
\text { Loss, \%) }\end{array}$} & \multirow{2}{*}{$\begin{array}{l}\text { Wet Surface } \\
\text { Adhesion } \\
\text { Strength } \\
\text { (De-Bonding } \\
\text { Time, s) }\end{array}$} & \multirow{2}{*}{$\begin{array}{l}\text { Hydrostatic } \\
\text { Pressure } \\
\text { (Leakage } \\
\text { Time, min) }\end{array}$} & \multirow{2}{*}{$\begin{array}{c}\text { Substrate } \\
\text { Behavioral } \\
\text { Stress } \\
\text { (Leakage } \\
\text { Time, min) } \\
\end{array}$} \\
\hline Materials & No. & & & & & & \\
\hline \multirow{4}{*}{$\begin{array}{c}\text { SPRG } \\
\text { A }\end{array}$} & 1 & 60 & 3.1 & 5 & 14 & 60 & 52 \\
\hline & 2 & 46 & 4.8 & 4 & 12 & 41 & 43 \\
\hline & 3 & 60 & 3.0 & 7 & 36 & 60 & 60 \\
\hline & Avg & 55.33 & 3.7 & 5 & 20.67 & 53.67 & 51.67 \\
\hline \multirow{4}{*}{$\begin{array}{c}\text { SPRG } \\
\text { B }\end{array}$} & 1 & 36 & 2.1 & 3 & 60 & 60 & 60 \\
\hline & 2 & 37 & 0.6 & 5 & 60 & 60 & 39 \\
\hline & 3 & 42 & 2.7 & 7 & 60 & 60 & 49 \\
\hline & Avg & 38.33 & 1.8 & 5 & 60 & 60 & 49.33 \\
\hline \multirow{4}{*}{$\begin{array}{c}\text { SPRG } \\
\text { C }\end{array}$} & 1 & 48 & 3.4 & 21 & 24 & 60 & 60 \\
\hline & 2 & 60 & 2.4 & 7 & 32 & 60 & 60 \\
\hline & 3 & 35 & 3.1 & 1 & 6 & 60 & 60 \\
\hline & Avg & 47.67 & 3.0 & 10 & 20.67 & 60 & 60 \\
\hline
\end{tabular}

\subsection{Grout-Injection Material Physical Property Change Measurement Comparison Results}

In order to provide an easier relative comparison, ratios derived from the test methods results of the respective test methods were calculated into percentage index (out of $100 \%$ ) based on the performance criteria outlined in the national standard test methods through Equations (1)-(6). Refer to the following Table 10 for details. 
Table 10. The physical properties change measurement comparison results of grout-injection materials.

\begin{tabular}{|c|c|c|c|c|c|c|c|}
\hline \multicolumn{2}{|c|}{ Specimens } & \multicolumn{6}{|c|}{ Properties Change Ratios } \\
\hline $\begin{array}{l}\text { Material } \\
\text { Type }\end{array}$ & No. & $\begin{array}{c}\text { Thermal } \\
\text { Stress }(\%) \\
\quad\left(\mathrm{T}_{t s}\right)\end{array}$ & $\begin{array}{c}\text { Chemical } \\
\text { Exposure }(\%) \\
\left(C_{l}\right)\end{array}$ & $\begin{array}{l}\text { Water flow } \\
\text { Erosion (\%) } \\
\quad\left(\mathrm{W}_{l}\right)\end{array}$ & $\begin{array}{c}\text { Wet Surface } \\
\text { Adhesion } \\
\text { Strength }(\%) \\
\left(\mathbf{A}_{i f}\right)\end{array}$ & $\begin{array}{c}\text { Hydrostatic } \\
\text { Pressure }(\%) \\
\left(\mathrm{T}_{h p}\right)\end{array}$ & $\begin{array}{c}\text { Substrate } \\
\text { Behavioral } \\
\text { Stress (\%) } \\
\left(\mathrm{T}_{s b}\right)\end{array}$ \\
\hline \multirow{3}{*}{$\begin{array}{l}\text { Acrylic } \\
\text { Resin }\end{array}$} & A & 63 & 52.6 & 313 & 0 & 43 & 100 \\
\hline & B & 47 & 44.0 & 219 & 23 & 5 & 33 \\
\hline & $\mathrm{C}$ & 20 & 36.8 & 202 & 0 & 0 & 0 \\
\hline \multirow{3}{*}{ Epoxy Resin } & A & 0 & 73.6 & 27 & 0 & 0 & 29 \\
\hline & B & 24 & 66. & 27 & 0 & 0 & 41 \\
\hline & $\mathrm{C}$ & 23 & 55.0 & 40 & 0 & 31 & 100 \\
\hline \multirow{3}{*}{$\begin{array}{l}\text { Polyurethane } \\
\text { Grout }\end{array}$} & A & 69 & 105.2 & 67 & 88 & 71 & 98 \\
\hline & B & 89 & 110.8 & 47 & 96 & 86 & 96 \\
\hline & $\mathrm{C}$ & 87 & 107.8 & 140 & 74 & 59 & 91 \\
\hline \multirow{3}{*}{ SPRG } & A & 8 & 24.4 & 33 & 66 & 11 & 14 \\
\hline & B & 36 & 11.9 & 33 & 0 & 0 & 18 \\
\hline & C & 21 & 19.8 & 67 & 66 & 0 & 0 \\
\hline
\end{tabular}

A radar chart for the respective grout-injection material type physical properties measurement was derived to allow a comprehensive comparison of the independent property changes after subjection to the six degradation conditions. The variation in the index of each axis indicates the degree of expected properties change with respect to each degradation factors. A higher percentage indicates a greater degree of physical properties change due to exposure to the specific degradation condition. In the case of chemical exposure resistance testing and water flow erosion resistance testing results, a mass loss ratio determined to be more than $100 \%$ relative to the standard mass loss threshold was not expressed past the $100 \%$ maximum in the final results to establish a regime for a relative comparison with the other properties. A higher percentage in the radar axis indicates a greater degree of physical property changes, which subsequently indicates the risk of waterproofing performance deterioration. Refer to the following radar charts below from Figures 13-16 for details.

Acrylic Resin Grout Comprehensive Evaluation Results

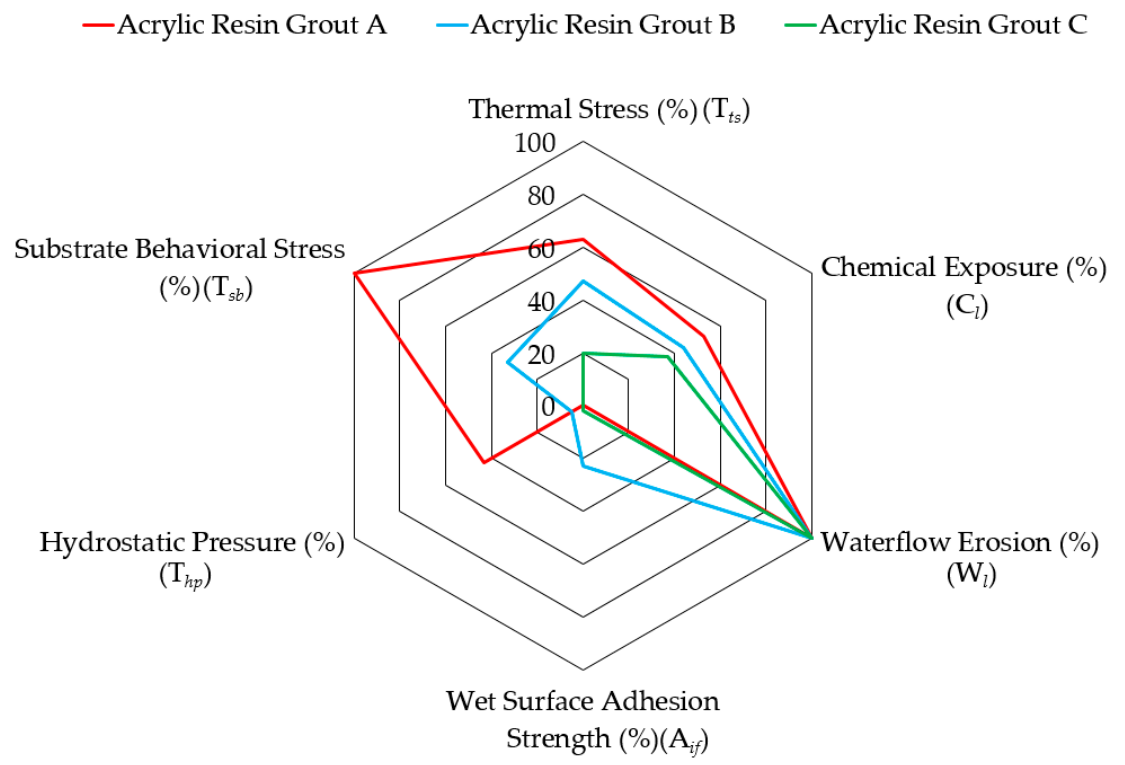

Figure 13. The physical property changes of the acrylic-resin grout-injection material. 
Epoxy Resin Comprehensive Evaluation Results

—Epoxy Resin Grout A —Epoxy Resin Grout B -Epoxy Resin Grout C

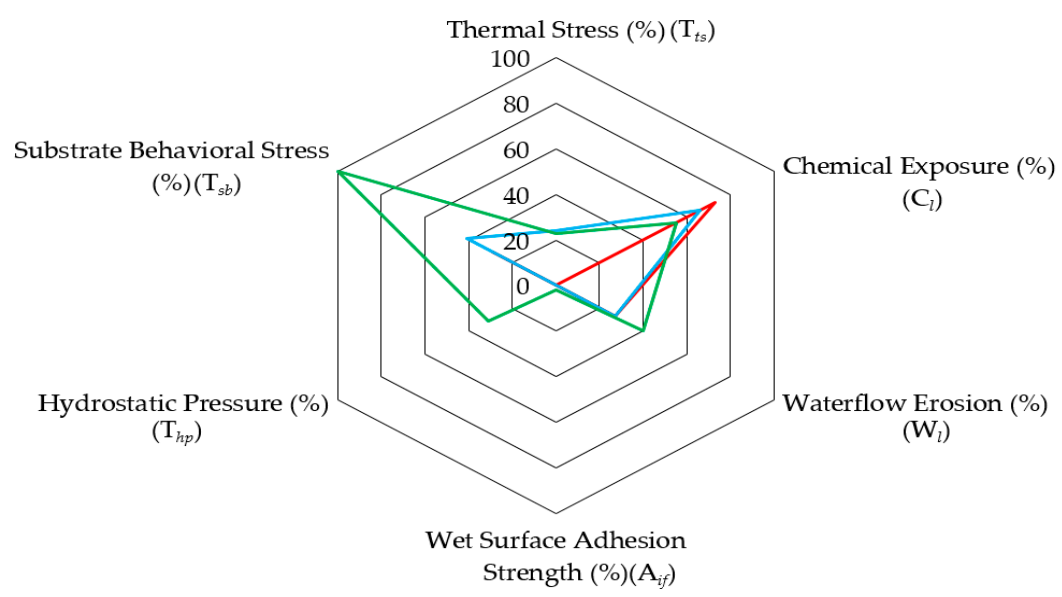

Figure 14. The physical property changes of the epoxy-resin grout-injection material.

Polyurethane Foam Grout Comprehensive Evaluation Results

—Polyurethane Foam Grout A - Polyurethane Foam Grout B - Polyurethane Foam Grout C

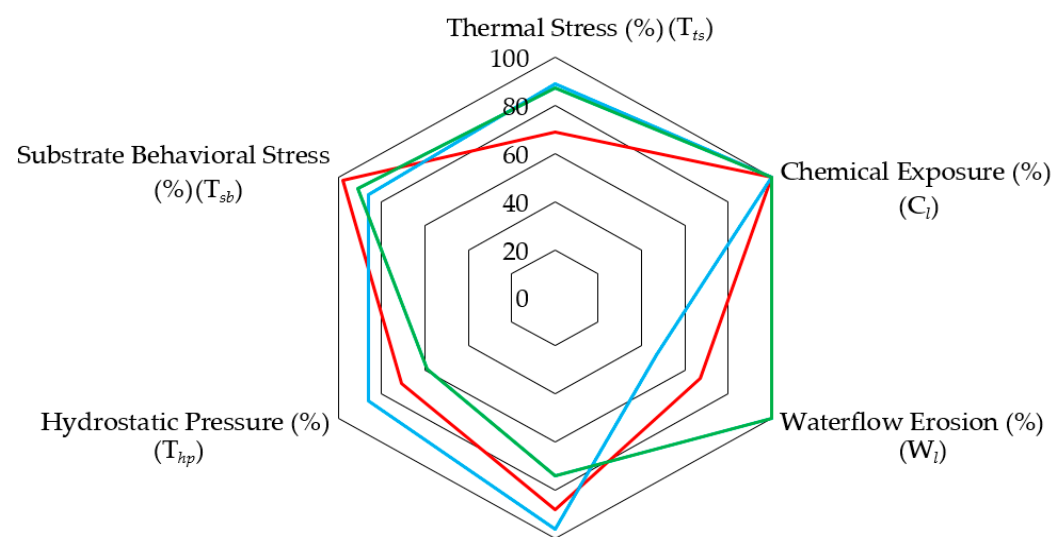

Wet Surface Adhesion

Strength (\%) $\left(\mathrm{A}_{i f}\right)$

Figure 15. The physical property changes of the polyurethane-foam grout-injection material.

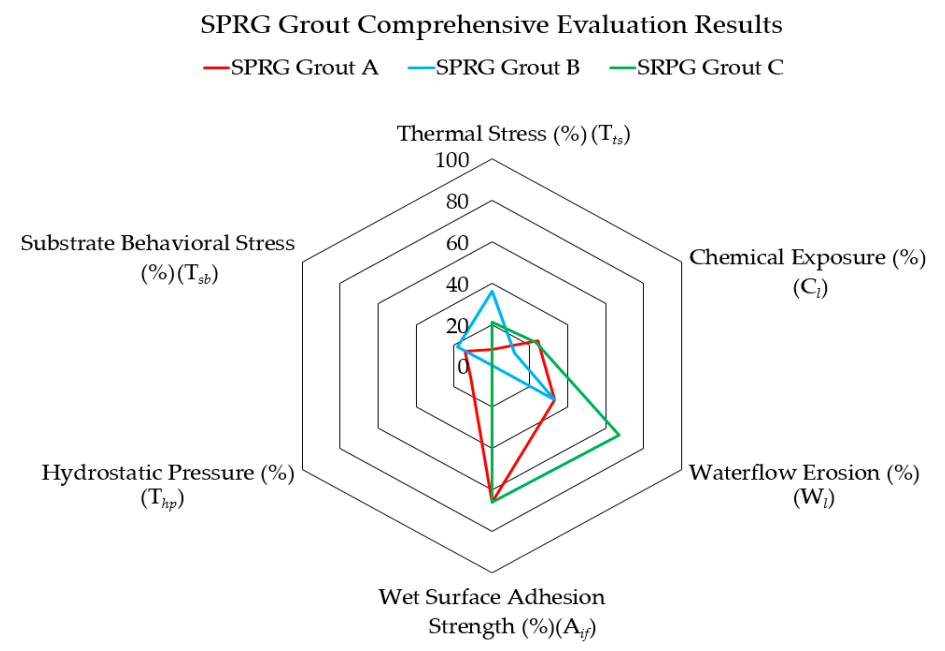

Figure 16. The physical properties change of the SPRG grout-injection material. 


\subsubsection{Acrylic-Resin Grout-Injection Material}

The physical property changes of the three different acrylic resin grout injection specimens were mutually compared. The results are shown that the three acrylic resin products are all relatively susceptible to physical property changes under the effect of water flow erosion and substrate behavioral stress. Product $C$, in particular, showed a higher stability than the other two products with regards to the degradation factors. Refer to the below radar chart in Figure 13.

\subsubsection{Epoxy-Resin Grout-Injection Material}

The physical property changes of the three different epoxy-resin grout-injection specimens were mutually compared. The results are shown that the three epoxy resin products are all relatively susceptible to physical property changes under the effect of chemical exposure and substrate behavioral stress. Product A, in particular, showed a higher stability than the other two products with regards to the material degradation factors. Refer to the below radar chart in Figure 14.

\subsubsection{Polyurethane-Foam Grout-Injection Material}

The physical property changes of the three different polyurethane grout-injection specimens were mutually compared. The results are shown that the three polyurethane products are susceptible to a large degree of physical property changes under all degradation factors. Refer to the below radar chart in Figure 15.

\subsubsection{SPRG Grout-Injection Material}

The physical property changes of the three different SPRG grout-injection specimens were mutually compared. The results are shown that the three SPRG products were somewhat susceptible to physical property changes with regards to wet surface adhesion strength and water flow erosion. Product $B$, in particular, showed a higher stability than the other two products. Refer to the below radar chart in Figure 16.

\subsection{Inclusive Comparison of the Four Types of Grout-Injection Materials}

Based on the above presentation of four types of grout-injection materials, a complete comparison of the physical property (waterproofing performance) changes are provided in the total radar chart of Figure 17.

The comparison results showed that the polyurethane-foam grout injection had a more significant performance degradation (physical change) in six degradation factors than the other types of materials. In the case of SPRG grout-injection materials, their performance change was minimal relative to the changes displayed in other materials types. For acrylic-resin grout-injection materials, their performance change with respect to substrate movement and exposure to continuous water flow were shown to be high. For epoxy-resin grouts, property changes to chemical exposure were relatively high. For polyurethane-foam grouts, all products showed a high degree of property changes after exposure to all degradation factors.

For the purpose of demonstration, a conclusion could be made based on the comprehensive evaluation results that the SPRG material overall had the least physical property changes (relative to the performance standard regimes and environmental degradation degree variables compliant to the KS F 4935 standard), but it is advised that, in construction sections where a constant presence of water or humidity, a usage of this material is not recommended. Similarly, acrylic-resin injection materials are subject to properties change where substrate behavioral stress is present, indicating that repairs with these materials in areas where a reopening of cracks due to settlement or vibrations is not recommended. Epoxy-resin grout usage should be avoided in areas where chemical substances are expected to be present. Polyurethane grout-injection materials are generally not recommended to be used for repair in below-grade concrete structures as a standalone material. 
Grout Injection Materials Comprehensive Evaluation Results (4 types)

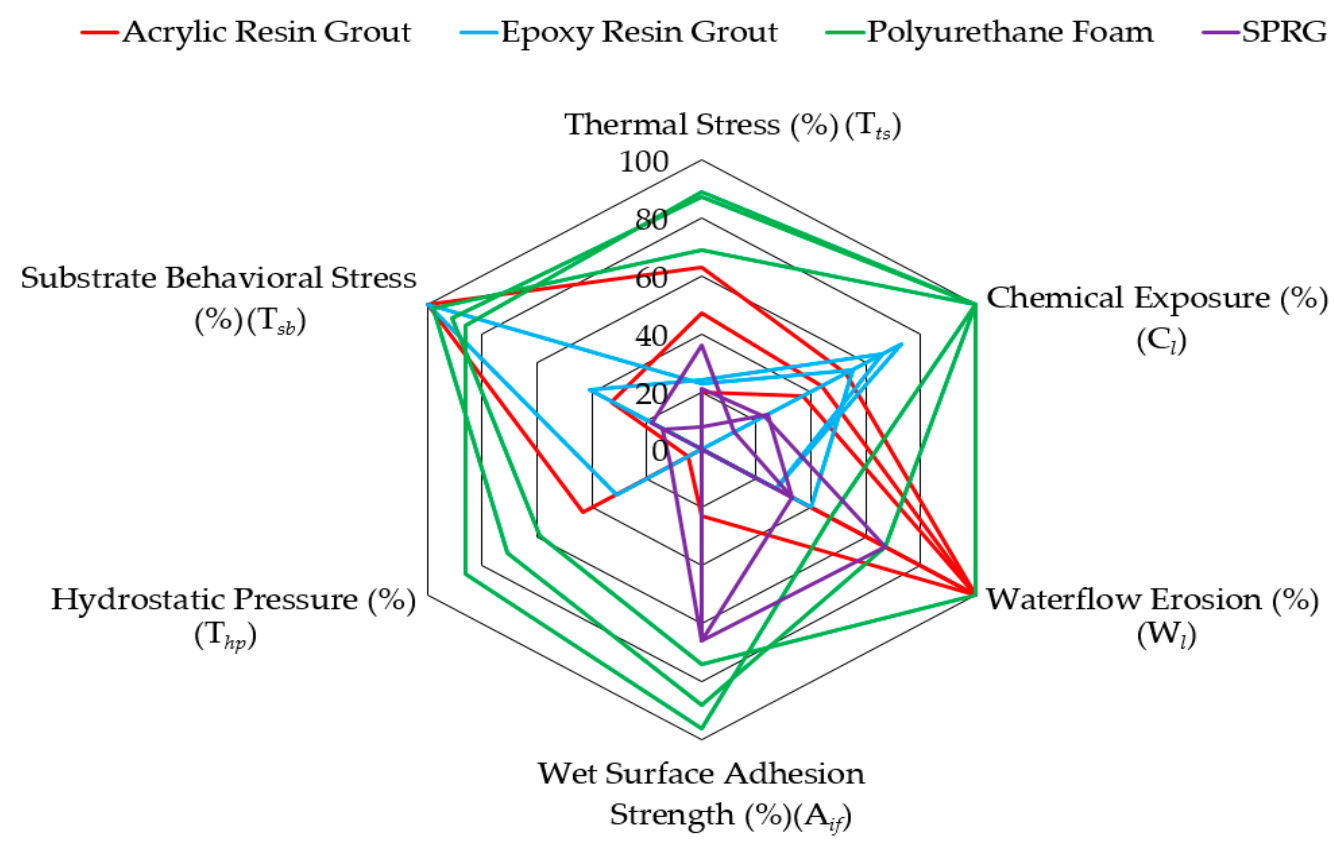

Figure 17. A comprehensive evaluation result of the four types of grout-injection materials.

A decisive conclusion cannot be readily made on the performance of these repair materials in this particular paper, as the evaluation was conducted using product specimens from Korea that were already expected to have certain types of results, as a means to demonstrate this technical evaluation method. If other materials from different companies or countries were to be used, different results may be expected for the respective types of material products (although not significantly different). The priority of this paper is to propose this technical evaluation and its functionality in being able to measure the different ratios of property changes for any given types of injection-grout repair material. The results presented in this demonstration do not yet have substantial data to be able to conclude that a particular type of materials is best in different situations.

In this regard, it must be noted that the tested specimens in this study have all been limited to samples manufactured in Korea; thus, the comparison results in this study alone is not sufficient to claim that one material type is undoubtedly superior over the other types. However, the technical evaluation model can be applied to different national products and material types based on the relevant national standard or specifications to control the variables in the testing regimes to establish a more objective comparison outcome.

\section{Conclusions}

The demonstration of this technical evaluation method that compares the physical property changes due to environmental degradation factors in below-grade conditions of concrete structures and a facilitated comparison between (1) different products of the same grout-injection material type and (2) different types of grout-injection materials is made possible. As such, through this evaluation (ISO TS 16774 Test method) and an objective comparison of the advantages and disadvantages of the respective material types/products can be quantitatively distinguished.

The demonstration of this evaluation regime has also shown that grout-injection material types have different response performance levels to the common degradation effects in below-grade concrete structure environments and that the degrees at which these levels differ can be visually represented.

The study and analysis results in this paper presents only the data that reflects the environmental conditions and material types most common in Korea, which limits the validity of the conclusions about 
the performance of the respective material types. Nevertheless, it is hoped that this evaluation model, or a similar regime, can be applied in future selection processes of grout-injection repair materials.

Author Contributions: B.J., X.H., and S.-k.O. conceived and designed the experiments; B.J., K.-h.O., S.-Y.K., and X.H. performed the experiments and analyzed the data; B.J., S.-Y.K., K.-h.O., and S.-k.O. wrote the paper.

Funding: This research was funded by Residential Environment Research Program as part of Ministry of Land, Infrastructure and Transport of Korean government, grant number 19RERP-B082204-06.

Acknowledgments: This research was supported by a grant (19RERP-B082204-06) from the Residential Environment Research Program funded by the Ministry of Land, Infrastructure, and Transport of the South Korean government.

Conflicts of Interest: The authors declare no conflict of interest. The founding sponsors had no role in the design of the study; in the collection, analyses, or interpretation of the data; in the writing of the manuscript; and in the decision to publish the results.

\section{Abbreviations:}

ISO

KS

ASTM

BS EN

JIS

GB

SPRG

AHP
International Standard Organization

Korean Industrial Standards

American Society for Testing and Materials

British Standard

Japanese International Standard

Guo Biao (Chinese International Standard)

Synthetic Polymer Rubber Gel

Analytic Hierarchy Process

\section{References}

1. Chang, S.J. Advanced Technology of Waterproofing. J. Archit. Inst. Korea 2005, 49, 57-60.

2. Oh, S.K.; Shim, J.S. Maintenance for Leakage due to Cracking in Concrete Structures-Guidelines for Repair of Water-Leakage Cracks in Concrete Structures. J. Korea Concr. Inst. 2011, 23, 47-52.

3. Kim, D.B.; Lee, H.R.; Seo, H.J.; Park, J.S.; Oh, S.K. A Study on Guidelines and Selection Methods of Adequate Materials for Repair of Water-Leakage Cracks in Concrete Structures. J. Korea Concr. Inst. 2011, 5, 611-612.

4. Lee, J.-H.; Song, J.-Y.; Oh, S.-K. Leakage Situation and Main Leakage Areas of Domestic Residential Building Underground Parking Lots. J. Korean Recycl. Constr. Resour. Inst. 2016, 4, 496-503.

5. Oh, S.-K. A Study on Guidelines for the Repair of Water-Leakage Cracks in Concrete Structures. J. Korean Inst. Constr. 2010, 10, 97-107. [CrossRef]

6. International Organization for Standardization Technical Committee 71 Subcommittee 7 Working Group 3. ISO TR 16475:2011 Guidelines for the Repair of Water-leakage Cracks in Concrete Structures; International Organization for Standardization: Geneva, Switzerland, 2011.

7. International Organization for Standardization Technical Committee 71 Subcommittee 7 Working Group 3. ISO TS 16774:2011 Parts 1-6, Guidelines for the Repair of Water-leakage Cracks in Concrete Structures; International Organization for Standardization: Geneva, Switzerland, 2017.

8. Oh, S.K. Cause Analysis and Leakage Repair Material and Method Selection for Leakage Crack Repair. Constr. Manag. News 2012, 4, 74-81.

9. An, K.W.; Kim, S.R.; Oh, S.K. Development and Study on the Future Employment of Waterproofing Design Guideline for Leakage Prevention of Residential Underground Structure. J. Archit. Inst. Korea 2017, 37, 1073-1074.

10. Lee, H.J.; Lee, J.H.; Kwak, K.S.; Oh, S.K. The test investigation regarding an efficiency on Leaking Repair Materials into Injection for Water Expansion Acrylic Resin System. J. Archit. Inst. Korea 2007, 27, 643-646.

11. Bean, D.L. Epoxy-Resin Grouting of Cracks in Concrete. Department of the Army -Final Report. 1985. Available online: https://apps.dtic.mil/dtic/tr/fulltext/u2/a164306.pdf (accessed on 5 March 2019).

12. Korea Land \& Housing Corporation. Establishment of Measures to Improve Quality of House Waterproofing Methods for Zero Defects in Quality Management; Public Housing Project Office: Seoul, Korea, 2017; pp. 1-3.

13. Pro, Ó. Water Control using polyurethane resins. In Proceedings of the 9th International Mine Water Association Congress, Oviedo, Asturias, Spain, 5-7 September 2005; pp. 289-293. 
14. Ahn, D.S. A Study on the Physical Properties Change of Synthetic Rubber Polymer Gel by Using Stirring Screw Mixer. Master's Thesis, Seoul National University of Science and Technology, Seoul, Korea, 2015.

15. Ahn, D.S.; Oh, K.H.; Park, J.S.; Oh, S.K. Viscosity and Waterproofing Performance Evaluation of Synthetic Polymerized Rubber Gel (SPRG) after Screw Mixing. Appl. Sci. 2018, 8, 1989. [CrossRef]

16. Park, W.G.; Kim, S.D.; Kim, D.B.; Park, J.S.; Kim, B.I.; Oh, S.K. Error Analysis and Improvement of KS F 4935 Sealer of Injection Type for Water Leakage Maintenance of Adhesive Flexible Rubber Asphalt Series』 Testing Method-Focus on Wet Substrate Surface Adhesion Performance Testing. Reg. Assoc. Archit. Inst. Korea 2017, 19, 131-138.

(C) 2019 by the authors. Licensee MDPI, Basel, Switzerland. This article is an open access article distributed under the terms and conditions of the Creative Commons Attribution (CC BY) license (http://creativecommons.org/licenses/by/4.0/). 